\title{
A Probabilistic Model of Assessment of Level Network Functionality
}

\section{Introduction}

Quality assessment of level networks by means of accuracy measures does not take into consideration the impact of the destruction process of the network. The process of destruction of the geodetic net geometry is an important problem in engineering practice. It always has a place although it runs with different intensity. Bad conditions of level network are illustrated by numerous signals. The significance of the problem brings up an exceptional scale of present investment programs. The problem is solved by modernization procedures which relays on the cyclic verification of the level marks condition and checking of accuracy criteria. The scope and number of modernizing works that have been undertaken in the last decade justifies the consciousness of negative results that can result from out of time data.

The problem of stability of levelling points is taken into consideration in technical standards. The regulations recommend localizations and construction details of marks based on practical questions and physical features of the destruction process such as changes of physical soil parameters, unstable static loads, the impact of the dynamic load from railroad lines, road traffic and industrial objects, unstable level of ground water, natural and artificial slopes of ground surface. Although the way of stabilization of elevation marks is of a great importance, it does not have an alternative for highly said modernization and updating measurements of the network. Generally, as engineering practice shows, the problem of instability of control points is significant as up to date measurements are carried out too rarely.

According to the standards [3] the modernization of the $1^{\text {st }}$ and $2^{\text {nd }}$ class level networks should be carried out in a period of less than twenty years. But, it should be emphasized, there are no similar recommendations in the case of the $3^{\text {rd }}$ class level network, which is particularly interesting for geodetic practice. That is why

* Kielce University of Technology, Faculty of Environmental, Geomatic and Energy Engineering, Kielce, Poland

** Cracow University of Technology, Faculty of Environmental Engineering, Krakow, Poland 
levelling networks are updated only in a few decades' intervals. On the other hand, the lack of detailed recommendations is apologized due to the specifics of the local conditions of every individual control network. According to the thesis formed by the authors, it is possible to optimize this period, if the assessment of the control level network is carried out on the base of a reliability model of the network taking into consideration the specificity of process destruction on the area of measurement.

\section{Theoretical Bases of the Reliability Approach}

At technical analysis, a reliability is defined by the probability that an object or system fulfills the technical requirements in the determined interval $\left[t_{0}, t\right]$, where $t_{0}$ is the time of beginning of the planned object operation. In other words, the main purpose of reliability analysis gives an answer to the practical question: what part of the objects will be in the state of usability in the determined future. In the mathematical model of the question a reliability function $R(t)$ called also a survival function determines the probability of the surviving period $\langle 0, t>$. The beginning of that period is a moment of delivery of object to operate:

$$
\begin{gathered}
R(t)=P\left\{t_{N} \geq t\right\}, \text { for } t \geq 0 \\
R(t)=1-P\left\{t_{N}<t\right\} \\
R(t)=1-F(t)
\end{gathered}
$$

where $F(t)$ is a cumulative function of random object life [2].

Failure rate function (or hazard function) $\lambda(t)$ is strictly related with the functions $R(t), \lambda(t), F(t)$. The function shows the probability that the object will be in failure condition in the time $t$. By definition it is:

$$
\lambda(t)=-\frac{d}{d t}[\ln R(t)]
$$

To solve a reliability problem one of the three functions i.e. $R(t), F(t)$ or $\lambda(t)$ has to be determined. It is only possible by empirical investigations. In typical practical reliability problems, the failure rate function) $\lambda(t)$ is assumed, usually:

$$
\lambda(t)=a=\text { const }
$$

Based on formulas (3) and (4):

$$
a=-\frac{d}{d t}[\ln R(t)]
$$

the reliability function $R(t)$ is:

$$
R(t)=e^{-a t}
$$


Value $a$ is the number of defects identified as the incorrectness of the system's operating found in the determined time interval.

\section{Reliability of Levelling Control}

Levelling network quality and usefulness of the control level network depends on the number of marks which can be used at measurements. Destruction of geometry is revealed as double-sided. On the one hand, level marks can be damaged or destroyed and on the other hand their elevations do not meet the expectations of the maintenance requirements. The process of using up the control network or adequately its stability can be described by means of the mathematical model of reliability. A proposal of the operational reliability model of a geodetic object by means of risk function has been given in the paper [5] and developed in [1].

According to the theoretical principles given above, the reliability function $R(t)$ is determined by the term, that a failure risk function $\lambda(t)=a=$ const. The variable $a$ is determined by statistic way. The purpose of the experiment is to find what part of the elevation marks fulfill criteria of usability and stability. The result of research on sample population is identified with the general population which covers all of the marks of the levelling net on the researched area.

The results of field research are:

$P_{h}$ - the probability that a point grants the criteria of both usability and stability,

$P_{u}$ - the probability that a point grants the criterion of usability,

$P_{s}$ - the probability that a point grants the criterion of stability.

$$
P_{h}=\frac{n_{h}}{N_{h}}, \quad P_{u}=\frac{n_{u}}{N_{u}}, \quad P_{s}=\frac{n_{s}}{N_{s}}
$$

Based on $P_{h^{\prime}} P_{u}$ and $P_{s}$ values of failure, risk functions $\lambda_{h^{\prime}} \lambda_{u}$ and $\lambda_{s}$ are found.

According to probability theory the assumption that a levelling mark fulfills both conditions of usability and stability can be noted in the formula:

$$
\begin{gathered}
P_{h}=P_{u} \cdot P_{s} \\
\ln P_{h}=\ln P_{u}+\ln P_{s}, \\
\ln \frac{n_{h}}{N_{h}}=\ln \frac{n_{u}}{N_{u}}+\ln \frac{n_{s}}{N_{s}}, \\
\frac{\ln \frac{n_{h}}{N_{h}}}{T}=\frac{\ln \frac{n_{u}}{N_{u}}}{T}+\frac{\ln \frac{n_{s}}{N_{s}}}{T}, \\
\lambda_{h}=\lambda_{u}+\lambda_{s}
\end{gathered}
$$


According to (9) the value $\lambda_{h}$ which is necessary to determine the reliability function $R(t)$ is determined by the addition of the usability and stability characteristics. It also results from the presented considerations that the value $\lambda_{h}$ can be found by two methods. The first may be defined as an direct one and the other as indirect one. In the direct method:

$$
\lambda_{h}=\frac{-\ln \frac{n_{h}}{N_{h}}}{T_{h}}
$$

where:

$N_{h}$ - the number of trial population,

$n_{h}$ - the number of leveling marks that fulfill two conditions: usability and stability,

$T_{h}$ - the period of the research [years].

The direct method cannot be applied if usability and stability studies are executed separately, e.g. on different sets of leveling net points or in different periods of times. In such case the value $\lambda_{u}$ is found based on the results of an inventory of the leveling net by formulae:

$$
\lambda_{u}=\frac{-\ln \frac{n_{u}}{N_{u}}}{T_{u}}
$$

where:

$N_{u}$ - the number of points examined by inventory survey,

$n_{u}$ - the number of marks that fulfill usability conditions,

$T_{u}$ - the period of research [years].

A value $\lambda_{s}$ is found by the measurements of the differences in elevations of marks:

$$
\lambda_{s}=\frac{-\ln \frac{n_{s}}{N_{s}}}{T_{s}}
$$

where:

$N_{s}$ - the number of examined differences,

$n_{s}$ - the number of stable differences in elevations,

$T_{s}$ - the period of the research [years].

Let us notice that in the case when all differences in elevation meet the demands of stability $\left(n_{s}=N_{s}\right)$ and the result of inventory is positive in all trial population $\left(n_{u}=N_{u}\right)$, then risk functions are $\lambda_{u}=\lambda_{s}=0, \lambda_{h}=0$ and reliability function is $R(t)=1$. 
The credibility of the identification of values $\lambda_{u}$ and $\lambda_{s}$ depends on the accuracy of finding $n_{u}$ and ns values. If the value $\lambda_{u}$ is determined correctly, the number of points which fulfill usability conditions is easy to identify. The result of investigation is much less precisely determined in the case of the research of the stability of the elevation marks to find $\lambda_{s}$ risk function. Having in mind practical arguments the authors assumed that the question of the stability of the levelling marks is identical with the problem of differences in elevations. The investigation is of statistical character and is carried out on arbitrary chosen marks of levelling net. According to the procedure used as a principle in engineering surveying values $d_{i}$ found as differences between the results of actual $\left(h_{p}\right)$ and previous $\left(h_{k}\right)$ measurements should fulfill the assumption:

$$
d_{i}=\left|h_{p i}-h_{k i}\right| \leq d_{\max }, i<1, N_{s}>
$$

A key point of analysis is an arbitrary assumption of $d_{\max }$ value that has to be found separately for each leveling line.

There are two methods to solve this problem. The first one can follow the procedure of identification of stable benchmarks applied in engineering surveying. According to this procedure a coefficient $t_{i}$ is found by formulae:

$$
t_{i}=\frac{d_{i}}{s_{d}}
$$

The value $t_{i}$ shows how much the result of observations exceeds the standard error of measurement $\left(s_{d}\right)$. Marks are assumed as the stable ones if $t_{g r} \leq 2$. The assumption that the critical value is equal twice as the standard error is arbitrary.

The method recommended by the authors takes into consideration technical obligatory regulations referring to the 3rd class leveling network. According to [3] the difference in elevation per $1 \mathrm{~km}$ line should be determined with standard error $4 \mathrm{~mm} / 1 \mathrm{~km}$. In the case of the levelling of the optional length of line $(L)$ the standard error can be found basing on proper weights. The weights are calculated as inverses of distances between the elevation marks by means of formula:

$$
\begin{gathered}
\frac{p_{l}}{p_{1 \mathrm{~km}}}=\frac{s_{1 \mathrm{~km}}^{2}}{s_{l}^{2}} \\
s_{l}=s_{1 \mathrm{~km}} \sqrt{\frac{p_{1 \mathrm{~km}}}{p_{l}}}
\end{gathered}
$$

The boundary value $d_{\max }$ is determined by (14) and (15) formula:

$$
\left|d_{\max }\right| \leq \sqrt{2} t s_{l}
$$


Having in mind that confidence interval is usually determined at $95 \%$ probability level, the value $t=2$ :

$$
\left|d_{\max }\right| \leq 2,8 s_{1 \mathrm{~km}} \sqrt{\frac{p_{1 \mathrm{~km}}}{p_{l}}}
$$

Based on formula (17) it can be found that in the case of $400 \mathrm{~m}$ levelling distance the difference between catalog data and the result of actual measurement cannot exceed the value of $7.3 \mathrm{~mm}$.

\section{Estimation of Credibility of Destruction's Prediction of Levelling Network}

It is the main purpose of the presented research is to predict a destruction process by means of a failure rate function $\lambda(t)$, cumulative function $F(t)$, or in the case of levelling network by means of $R(t)$ function a number of marks which are going to fulfill survey demands in a determined period in future, is determined. It is very difficult to assess a credibility of a reliability approach, and the result is only approximate in every case.

The estimation can be done by different methods. At the presented problem the best assessment would give the analysis of the sensitivity of the model. The more simple way, although the not so accurate one, consists in the application of the probabilistic propagation law. According to the last one approach and assuming that the variables of reliability function (6) are random ones a standard error $s_{R}$ is determined by a formula:

$$
s_{R}=t \cdot \exp \left(\lambda_{h} \cdot t\right) s_{\lambda h}
$$

where the standard error of variable defines formula:

$$
s_{\lambda h}=\frac{1}{T} \sqrt{\frac{1}{n_{u}^{2}} s_{\lambda u}^{2}+\frac{1}{n_{s}^{2}} s_{\lambda S}^{2}}
$$

Formulae (18) and (19) can be used provided that dispersions of variables will be known. These values of standard errors depend on different conditions such as the geometry of network, size of research area and technology of measurement.

The values of the errors may be estimated by one of three procedures, as follows:

- It is possible to divide an area of research on several subareas and appoint values for all of the separate subsets. A large area of research is a condition for such method. At least several levelling marks should be within each subarea. 
- If research is going to be executed in different periods e.g. succeeding, then the results of these separate tests may be treated as elements of the new test population characterized by average value $\lambda_{\text {sr }}$ and standard error $\sigma_{\lambda}$ for $\lambda\left[\lambda_{h^{\prime}} \lambda_{u^{\prime}} \lambda_{s}\right]$. The $\lambda_{h}$ variable probably will be stable in the range of the influence of geotechnical soil specificity, but in a longer period of time it shows certain variability caused by interaction of investment activity on the research urban areas.

- Values of failure rate function $\lambda$ may be used based on research data from other leveling networks by applying the method of analogy. The networks should be situated in areas of similar geotechnical features and similar engineering and investment activity.

\section{Predictions of Conditions of Levelling Networks in Practical Cases}

\subsection{Case Study: The Levelling Network in the Area of the City of Kielce}

The research of levelling network included 70 elevation marks existing in the central district area of Kielce. In particular the research included two leveling marks of $1^{\text {st }}$ class, two marks of $2^{\text {nd }}$ class and 56 marks of $3^{\text {rd }}$ class of levelling network. A test of stability has been executed on twenty differences in elevation between the marks of the network. A similar dispersion of points in the research area has been taken into consideration at choice of measured differences. The measurements were executed by code level Sokkia SDL50 characterized by accuracy of $1.5 \mathrm{~mm} / \mathrm{km}$ of double levelling. The research was carried out in 2014, and its results were compared with a condition of network from the year of 1968.

Table 1. Results of the research in Kielce leveling network in the period of 1968-2014

\begin{tabular}{||c|c|l||}
\hline \multicolumn{2}{|c|}{$\begin{array}{c}\text { Researches of usability of network marks } \\
\text { Results of inventory survey }\end{array}$} & $\begin{array}{c}\text { Researches of stability } \\
\text { Measurements of differences in elevations }\end{array}$ \\
\hline \hline Total number of marks in 1968 & 118 & Differences examined \\
\hline Total number of marks in 2014 & 70 & Unstable differences \\
\hline Number of usable marks in 2014 & 58 & Stable differences \\
\hline Number of existing but unusable marks (2014) & 12 & \multicolumn{1}{|c||}{} \\
\cline { 1 - 2 } Marks destroyed (2014) & 48 & \multicolumn{2}{|c|}{} \\
\hline
\end{tabular}

Data in Table 1 show that after forty-six years (1968-2014) only 49\% of network marks (58/118) meet the condition usability. One can point to investment works, repairs of buildings, heat-insulating works or building demolitions as causes of 
so great a decrease in the number of usable elevation points. The research of the stability of the differences in elevations carried out by the leveling method of the increased accuracy show, that the criterion of the stability (13) fulfills $75 \%$ of the leveling marks.

The prediction of the stability of examined network was based on the reliability function $R(t)$ according to formula (6). The values $\lambda_{u}$ and $\lambda_{s}$ were appointed on data: $N_{u}=118, n_{u}=58, T=46$ (Tab. 1$)$ :

$$
\lambda_{u}=\frac{-\ln \frac{58}{118}}{46}=0.0154 / \text { year }
$$

The value $\lambda_{s}$ was found based on data: $N_{s}=20, n_{s}=15, T_{s}=46$ :

$$
\lambda_{s}=\frac{-\ln \frac{15}{20}}{46}=0.0062 / \text { year }
$$

The value of risk function $\lambda_{h}$ is determined by the sum of the reliability variables e.g. usability and stability (9):

$$
\lambda_{h}=0.0216 / \text { year }
$$

The results of the prediction of the network destruction have been calculated for operation periods: $t[5,10,15,20]$ [years] are given in Table 2 .

Table 2. Prediction of destruction of the Kielce levelling network

\begin{tabular}{|c|c|c|c|c|c|c||}
\cline { 2 - 7 } \multicolumn{1}{c|}{} & \multicolumn{7}{c||}{ Year } \\
\cline { 2 - 7 } \multicolumn{1}{c|}{} & 1968 & 2014 & 2019 & 2024 & 2029 & 2034 \\
\hline \hline$T$ & 0 & 46 & 51 & 56 & 62 & 67 \\
\hline$R(t)$ & 0 & 0.37 & 0.33 & 0.30 & 0.26 & 0.24 \\
\hline $\begin{array}{l}\text { Number of points which meet } \\
\text { network operating specifications }\end{array}$ & 118 & 44 & 39 & 35 & 31 & 28 \\
\hline
\end{tabular}

\subsection{Case Study: The Levelling Network in the Area of the City of Lodz}

Research leveling networks which were carried out in the area of the city of Lodz included 74 marks dispersed in a large area of the central district. The research covered five marks of the $2^{\text {nd }}$ class and 69 marks of the $3^{\text {rd }}$ class of the state network. 
The stability test was carried out for 67 levelling lines. The levelling measurements were performed by means of set: precise Leica DNA 03 of $0.3 \mathrm{~mm} / \mathrm{km}$ accuracy and two invar staffs GPCL2 and GPCL3. The results of the research have been compared with data from 1992 (Tab. 3).

Table 3. Results of research of levelling network of the city of Lodz in the period 1992-2014

\begin{tabular}{||c|c|l||}
\hline \multicolumn{2}{|c|}{$\begin{array}{c}\text { Research of the usability of network marks } \\
\text { Results of inventory survey }\end{array}$} & $\begin{array}{c}\text { Research of the marks stability } \\
\text { Measurements of differences in elevation }\end{array}$ \\
\hline \hline Total number of marks in 1968 & 74 & Differences examined \\
\hline Total number of marks in 2014 & 68 & Unstable differences \\
\hline Number of usable marks in 2014 & 68 & Stable differences \\
\hline Number of existing but unusable marks (2014) & 0 & \\
\hline Marks destroyed (2014) & 6 & \\
\hline
\end{tabular}

After twenty-two years (1992-2014) of network operation the condition of usability was fulfilled by $92 \%$ of the levelling marks. The loss can be assessed as relatively low as well it is justified to point to small activity investment in the centre of Lodz is the reason of that result. A condition of stability determined by interval $t[2.0,5.4]$ was fulfilled by $75 \%$ of the levelling marks.

The researches of levelling networks on the areas of Kielce and Lodz are similar. However, this convergence is only of random character. The $\lambda_{h}$ values are similar, but its components are essentially different.

The prediction of operational reliability of the Lodz levelling network has been prepared by means of (6) based on data given in Table 3 . The value $\lambda_{u}$ has been found by formula (11) for data $N_{u}=118, n_{u}=58, T_{u}=46$ :

$$
\lambda_{u}=\frac{-\ln \frac{68}{74}}{22}=0.0038 / \text { year. }
$$

The value $\lambda_{s}$ has been found by formula (12) for data $N_{s}=67, n_{s}=50, T_{s}=22$ :

$$
\lambda_{s}=\frac{-\ln \frac{50}{67}}{22}=0.0133 / \text { year. }
$$

The sum of the usability and stability characteristics is:

$$
\lambda_{h}=0.0171 / \text { year } .
$$


The prediction of the destruction of the levelling network by means of reliability function (6) is presented in Table 4 . For periods of operating $t[5,10,15,20]$ the number of points which will meet operating conditions have been estimated.

Table 4. Prediction of the destruction of the Lodz levelling network

\begin{tabular}{|c|c|c|c|c|c|c||}
\cline { 2 - 7 } \multicolumn{1}{|c||}{} & \multicolumn{7}{|c||}{ Year } \\
\cline { 2 - 8 } & 1992 & 2014 & 2019 & 2024 & 2029 & 2034 \\
\hline \hline$T$ & 0 & 22 & 27 & 32 & 37 & 42 \\
\hline$R(t)$ & 0 & 0.69 & 0.63 & 0.58 & 0.53 & 0.49 \\
\hline $\begin{array}{l}\text { Number of points which } \\
\text { meet network operating } \\
\text { specifications }\end{array}$ & 118 & 81 & 74 & 68 & 62 & 57 \\
\hline
\end{tabular}

\section{Conclusions}

- The process of the degradation of levelling networks can be modeled on the reliability approach. In geodetic practice applying reliability analysis is particularly effective in the case of the assessment of the $3^{\text {rd }}$ class levelling network which are stabilized in compact settlement areas.

- A reliability model and a prediction of network state take into account local conditions impact, first of all the geotechnical conditions and the intensity of investment processes. The models should be updated in the course of obtaining researched data.

- Practically and theoretically justified is identifying a stability of levelling marks with stability of differences in elevations.

- Essential and an ambiguous element of the practical reliability task is the assumption of critical values of changes of differences in elevations in the formula (13). For this purpose, the procedure for identifying a reference system may be adopted. This method is effective in geodesy engineering analysis, but it is handicapped in reliability problem as it does not consider regulations given by technical standards [3, 4].

- An investigation of the degradation processes of the levelling networks should be conducted in such a way that findings formulated on that basis could be used in making decisions regarding the range of modernization and renovation. 


\section{References}

[1] Derezińska A., Wolski B.: Badania niezawodności eksploatacyjnej punktów osnowy wysokościowej na obszarach gruntów ekspansywnych. Czasopismo Techniczne. Środowisko, r. 105, z. 2-Ś, 2008, pp. 85-94.

[2] Migdalski J. (red.): Poradnik niezawodności: T. 2, Inżynieria niezawodności: poradnik. Zetom, Warszawa - Bydgoszcz 1992.

[3] Rozporzadzenie Ministra Administracji i Cyfryzacji z dnia 14 lutego 2012 r. w sprawie osnów geodezyjnych, grawimetrycznych i magnetycznych. Dz.U. 2012, poz. 352.

[4] Rozporzadzenie Ministra Spraw Wewnętrznych i Administracji z dnia 9 listopada $2011 r$. w sprawie standardów technicznych wykonywania geodezyjnych pomiarów sytuacyjnych $i$ wysokościowych oraz opracowywania i przekazywania wyników tych pomiarów do państwowego zasobu geodezyjnego i kartograficznego. Dz.U. 2011, nr 263, poz.1572.

[5] Wolski B.: Operational reliability of geodetic control points. Geodezja i Kartografia, vol. 56, no. 2, 2007, pp. 83-94. 